\title{
CHICKEN MITE: EPIDEMIOLOGICAL ASPECTS OF DISTRIBUTION
}

\section{Nagorna Liudmyla ${ }^{1}$ \\ Proskurina Irina ${ }^{2}$}

\section{DOI: https://doi.org/10.30525/978-9934-571-89-3_88}

The world's industrial poultry industry faces a number of insurmountable problems, in particular parasitization on poultry and production facilities of various types of mites (Acari) [1, p. 69; 2, p. 12;3, p. 25]. The problem of colonization of poultry breeding facilities by chicken mites is also relevant for modern poultry farming in Ukraine, regardless of soil and climate conditions. A huge problem is the chicken tick Dermanyssus gallinae when laying hens. From the parasitization of chicken mites, poultry farms suffer from both floor and cell-battery methods of keeping the poultry. At the latter, it is much more difficult to carry out a set of deactivation measures, since the bulk of the ectoparasites is localized in hard-toreach places for processing, at the corners of technological equipment and crevices. Because of this, in some cases insecto-acaricidal drugs do not get enough to the colony of ticks. The problem of dermanisiosis is extremely acute in the springsummer period, which is associated with an increase in the temperature of the environment and activation of the development of ectoparasites, including in natural biotopes $[4$, p. $140 ; 5$, p. $150 ; 6$, p. 30]. Other productive birds are also susceptible to invasion by chicken mites [7, p. 181]. Chicken mite is one of the most common ectoparasites of laying hens in Europe. The damage from red mites for industrial egg production in the EU is 130 million euros annually at a total cost of 0.43 euros per chicken. In invasive livestock, it is noted: a decrease in the safety of livestock and egg production, a decrease in the quality of the products obtained, a deterioration in the conversion of fodder, the biological value of embryos and hatchability of eggs, an increase in susceptibility to various diseases of infectious etiology $[8$, p. $23 ; 9$, p. 442; 10, p. 862]. Promotes the spread of chicken tick very low selective activity. Susceptible to invasion are more than 30 species of birds, including synanthropic ones. This contributes to the further distribution of chicken mites in the biotopes. As a result, parasitological monitoring of poultry farms and poultry farms regarding the Dermanyssus gallinae tick is of great relevance in poultry farming $[11$, p. $68 ; 12$, p. 3$]$.

Research was carried out at poultry enterprises that specialize in the cultivation of different species and breeds of productive poultry: laying hens, broilers, turkeys, ducks, geese, quails, ostriches. In determining the epizootic situation, the technology of keeping the poultry and the season of the year was taken into account. The conditions of keeping and feeding the poultry corresponded to the current requirements (DSTU 2120-2002). A study of the taxonomic composition of ticks was carried out in I.I. Schmalhausen Institute of Zoology of the National Academy of

\footnotetext{
${ }^{1}$ Sumy National Agrarian University, Ukraine

${ }^{2}$ Sumy National Agrarian University, Ukraine 
Sciences of Ukraine. When carrying out a parasitological survey of poultry houses, we paid attention to the accumulation of dust on cellular batteries, under various technological equipment. Petri dishes were collected from 100 square meters of dust from ten locations in each house. Under laboratory conditions, they were placed near a heat source, heating to $35-40^{\circ} \mathrm{C}$, thereby activating the motor activity of ectoparasites. Selectively examined the bird, isolated from various sections of cellular batteries, paying attention to the underwing areas, head, stomach. At least 10-15\% of the poultry from each farm was subjected to inspection.

As a result of monitoring studies of poultry farms from the breeding of laying hens, when they were kept in cell batteries, $76.5 \%$ of the premises were invaded and populated with chicken mites. In industrial poultry farming, the intensity of invasion depended on the duration of maintenance of laying hens in poultry houses. Extensity of invasion was minimal $-23.5 \%$ in 2 months after planting birds in poultry houses and reached $100 \%$ before the end of the production cycle. When introducing chicken mites from outside from the outside into a prosperous farm, a high degree of colonization of the Dermanyssus gallinae was recorded in 80-100 days, with chickens in poultry houses. Eggs from dysfunctional poultry houses had characteristic contamination of the shell (Figure 1).

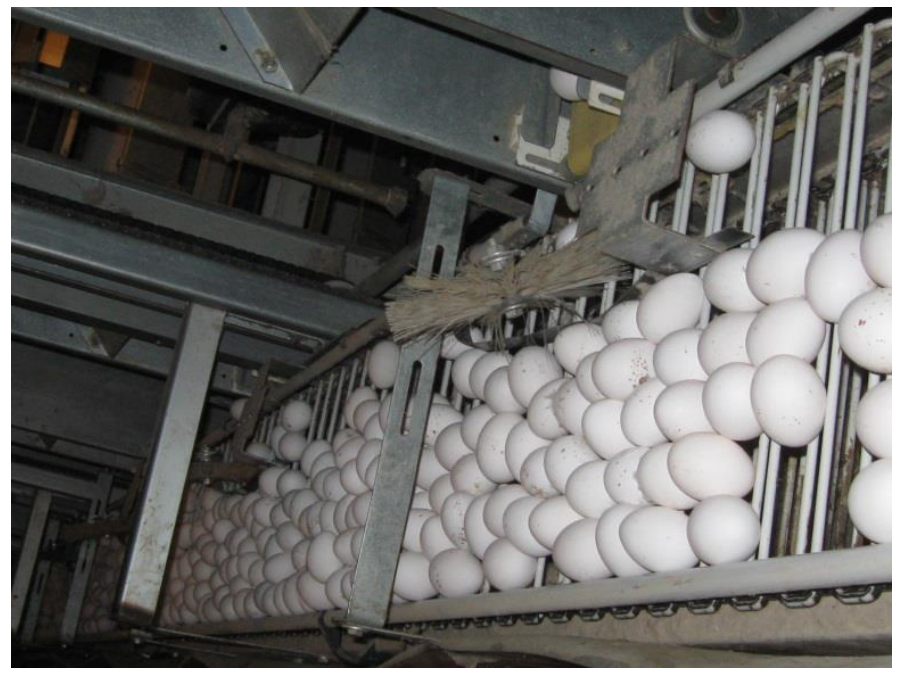

Figure 1. Chicken eggs contaminated with red mite

Layers in the industrial sector were free from acariform ticks Knemidocoptes mutans.Invasion of laying hens with chicken mites in private farmsteads was detected in $10.2 \%$ of cases. On the poultry of private mites, Knemidocoptes mutans were identified in $36.7 \%$ of cases when keeping chickens without replacement of the livestock for at least 3-5 years.

Under these conditions, poly-invasion was more often detected by mites and mallophages, in particular Dermanyssus gallinae + Menopon gallinae, Menacanthus stramineus; Dermanyssus gallinae + Menopon gallinae, Menacanthus stramineus + Knemidocoptes mutans, Menopon gallinae, Menacanthus stramineus + Knemidocoptes mutans. 
The extent of invasion by chicken mites reached a maximum in July-August, while the number of mallophages during this period was minimal. Chicken mite Dermanyssus gallinae was isolated in $12.3 \%$ of the surveyed broiler farms, with outdoor maintenance. The population of hen houses with chicken mites reached the average intensity of invasion on the 15th day of growing broilers, and on the $35-40^{\text {th }}$ day a high degree of colonization of the Dermanyssus gallinae was recorded (Figure 2).

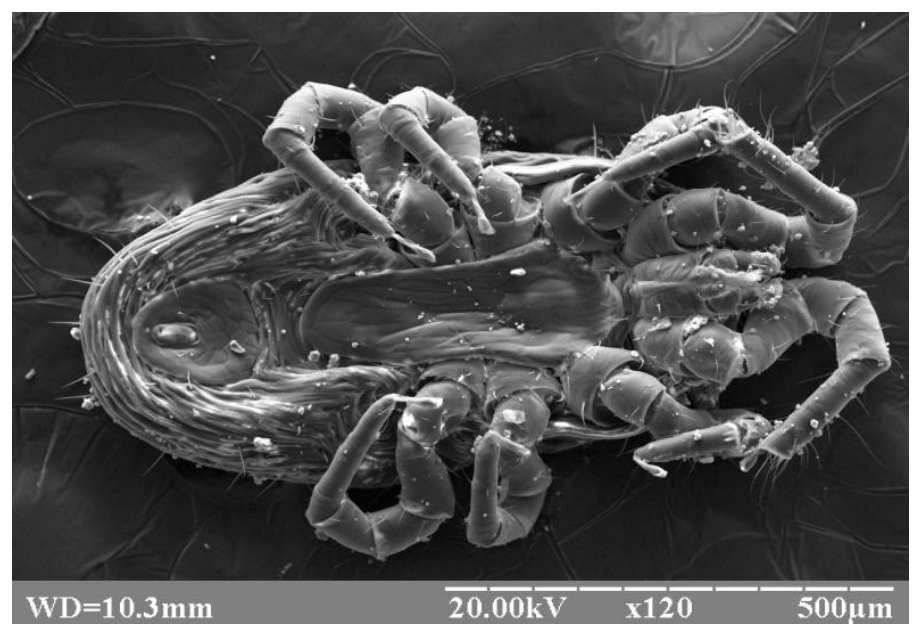

Figure 2. Imago of chicken mite Dermanyssus gallinae

About $28.5 \%$ of turkey farms, about $42.9 \%$ from quail breeding, $17.3 \%$ from breeding of poultry were unsuccessful relative to chicken mites. In the ostriches identified a specific mite Gabucinia bicaudata.

As a result of parasitological monitoring of poultry enterprises from breeding of productive birds, it was established that the colonization of their Dermanyssus gallinae with chicken ticks is widespread, regardless of the type, age and technology of keeping the poultry.

Over the past 7 years, the number of poultry farms affected by chicken mites has increased several folds.

\section{References:}

1. Biu A., Agbede R., Peace P. (2008) Studies on ectoparasites of poultry in Maiduguri, Nigeria. Nigerian Journal of Parasitology, no. 28, pp. 69-72.

2. George R. D., Olatunji G., Guy J. H., Sparagano O. A. (2010). Effect of plant essential oils as acaricides against the poultry red mite, Dermanyssus gallinae, with special focus on exposure time Veterinary Parasitology, no. 90, pp. 7-21.

3. Wang F. F., Wang M., Xu F. R., Liang D. M., Pan B. L. (2010). Survey of prevalence and control of ectoparasites in caged poultry in China. Veterinary Record Journal, no. 167, pp. 17-34.

4. Berezovskiy A. V., Nagorna L. V. (2016). Analysis of the epizootic situation regarding productive poultry's ectoparasites in Ukraine The Proceedings of XXV World's Poultry Congress, 5-9 September, China, p. 140.

5. Nagorna L. V., Berezovskiy A. V. (2016). Ektoparazyty yak chynnyky pohirshennya biobezpeky v umovakh ptakhivnychykh pidpryyemstv [Ectoparasites as factors of deterioration of biosafety in poultry farms]. Bulletin of Agrarian Science of the Black Sea Region no. 90, pp. 148-151. (in Ukrainian) 
6. Van Emous R. Wage war against the red mite! (2005). Poultry International, no. 44, pp. 26-33.

7. Nagorna L. V. (2014). Dermanisioz v sovremennom ptitsevodstve Ukrainy [Dermanisios in the modern poultry farming of Ukraine] Lucrari stiitifice: medicina veterinara, no. 40, pp. 180-182. (in Russian)

8. Mozafar ByF., Tierzucht L. (2014). Tackling red mite in laying hens remains a challenge. World Poultry, no. 30, pp. 22-24.

9. Sparagano O., George R. D., Harrington D., Giangaspero A. (2014). Biology, epidemiology, management and risk related to the poultry red mite, Dermanyssus gallinae. Annual Review of Entomology, no. 59, pp. 436-447.

10. Kilpinen O. (2001). Activation of the poultry red mite, Dermanyssus gallinae (Acari: Dermanyssidae), by increasing temperatures. Experimental and Applied Acarology 25: pp. 859-867.

11. Yakhchali M., Rasouli Alborzi E. (2013). Prevalence and body distribution of the poultry red mite in layer farms from Markazi province of Iran Iranian Journal of Veterinary Research, no. 14, pp. 4-72.

12. Sabuni Z., Mbuthia P., Maingi N., Nyaga P. (2010). Prevalence of ectoparasites infestation in indigenous free-ranging village chickens in different agro-ecological zones in Kenya. Livestock Research for Rural Development, no. 22, pp. 1-5. 